\title{
Review of Microbially Induced Corrosion and Comments on Needs Related to Testing Procedures
}

\author{
M. W. House and W. J. Weiss \\ Lyles School of Civil Engineering, Purdue University
}

\begin{abstract}
Concrete is the most widely used material for the construction of the wastewater collection, storage, and treatment infrastructure. The chemical and physical characteristics of hydrated Portland cement may make it susceptible to degradation under highly acidic conditions. As a result, some concrete wastewater infrastructure may be susceptible to a multistage degradation process known as microbially induced corrosion (MIC). MIC begins with the production of aqueous hydrogen sulfide $\left(\mathrm{H}_{2} \mathrm{~S}_{(\text {aq }}\right)$ by anaerobic sulfate-reducing bacteria present below the waterline. $\mathrm{H}_{2} \mathrm{~S}_{\text {(aq) }}$ partitions to the gas phase where it is oxidized to sulfuric acid by the aerobic sulfur-oxidizing bacteria Thiobacillus that resides on concrete surfaces above the waterline. Sulfuric acid then attacks the cement paste portion of the concrete matrix through decalcification of calcium hydroxide and calcium silica hydrate coupled with the formation of expansive corrosion products and loss of coarse aggregate. The attack proceeds inward, resulting in reduced service life and potential failure of the concrete structure. There are several challenges associated with assessing a concrete's susceptibility to MIC. First, no standard laboratory tests exist to assess concrete resistance to MIC. Straightforward reproduction of MIC in the laboratory is complicated by the use of microorganisms and hydrogen sulfide gas. Physicochemical tests simulating MIC by immersing concrete specimens in sulfuric acid offer a convenient alternative but do not accurately capture the damage mechanisms associated with biological corrosion. Comparison of results between research studies is difficult due to discrepancies that can arise in mixture design, specimen preparation, and experimental methods even if current ASTM standards are followed.
\end{abstract}

\section{INTRODUCTION}

Portions of the concrete wastewater infrastructure may be susceptible to a complex multistage deterioration process known as microbially induced corrosion (MIC; Islander, Devinny, Mansfeld, Postyn, \& Shih, 1991; Parker, 1951). The following steps outline how MIC works to degrade concrete exposed to wastewater (Figure 1):

- Sulfates in the waste stream are converted to aqueous hydrogen sulfide $\left(\mathrm{H}_{2} \mathrm{~S}_{(a \mathrm{a})}\right)$ through the activity of anaerobic sulfate-reducing bacteria under anaerobic conditions (dissolved oxygen (DO) levels $<0.1 \mathrm{mg} / \mathrm{L}$ ) below the waterline,

- $\mathrm{H}_{2} \mathrm{~S}_{(\mathrm{aq})}$ is released into the gas phase $\left(\mathrm{H}_{2} \mathrm{~S}_{(\mathrm{g})}\right)$ with or without the aid of turbulence (turbulence increases the gas release),

- $\mathrm{H}_{2} \mathrm{~S}_{(\mathrm{g})}$ partitions into the moisture layer present on surfaces above the water line where it is oxidized to sulfuric acid by several species of the aerobic bacteria Thiobacillus,

- Sulfuric acid attacks the cement paste portion of the concrete matrix through decalcification of calcium hydroxide and calcium silica hydrate and the formation of the expansive corrosion products gypsum and ettringite,

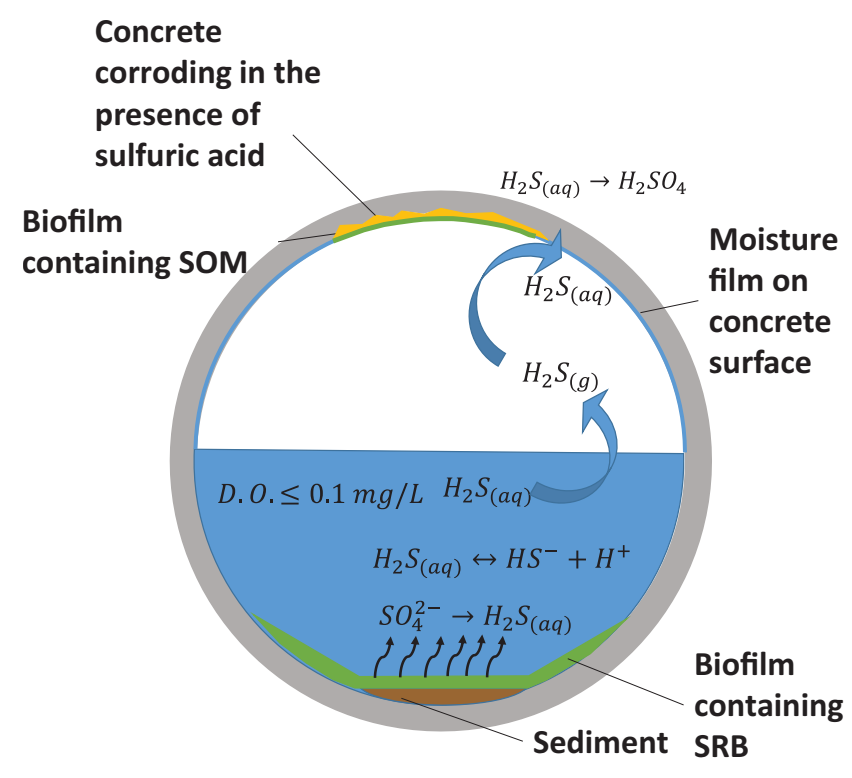

Figure 1. Schematic representation of the biochemical processes contributing to MIC of a concrete sewer pipe (Modified from Parker, 1951).

- Coarse aggregate is dislodged and thickness of concrete members is reduced as the attack proceeds into the structure.

The result can be a corrosion process that can compromise structural integrity and significantly 
reduce service life of concrete elements exposed to wastewater. It is worth noting that while the general chain of events leading to MIC is widely accepted, the corrosion behavior will vary based on the unique environmental conditions, waste stream behavior, structural characteristics, and material properties present in each case.

MIC in wastewater collection and treatment systems is well documented in most developed areas of the world including North America (Gutierrez-Padilla, 2007; U.S. EPA, 1991), Europe (Diercks, Sand, \& Bock, 1991), the Middle East (Saricimen, Shameem, Barry, Ibrahim, \& Abbasi, 2003), South Africa (Alexander \& Fourie, 2011), and Australia (Parker, 1951; Thistlethwayte, 1972). A 1991 EPA report estimated that the repair or replacement of 25 miles of corroded concrete sewer pipe in Los Angeles County alone would cost $\$ 130$ million (U.S. EPA, 1991). The United States currently maintains between 700,000 and 800,000 miles of sewer piping, much of which is well into its design life (ASCE, 2013), and while concrete sewer pipes are commonly the focus of discussion regarding MIC, it is important to consider that any concrete structures exposed to many municipal and industrial waste streams have the potential to experience damage from MIC.

Despite the current knowledge base, the fundamental mechanisms of MIC have not been thoroughly defined. Efforts to predict damage from MIC through the use of mathematical models are focused on the limited case of circular concrete sewer pipes and rely heavily on empirical evidence. The complex nature of microbiological testing coupled with the used of hazardous materials has prevented the development of convenient and repeatable laboratory test methods. As a result, test methods developed to mimic MIC in the laboratory are often complex, time intensive, and cost prohibitive. This has led to the development of simplified and accelerated testing methods that may not accurately capture the damage mechanisms associated with MIC. Furthermore, the lack of standardized testing methodologies for evaluating concrete resistance to MIC results in inconsistent findings and prohibits straightforward comparison between laboratory analyses.

The main objectives of this paper are to provide a review of the main concepts regarding MIC in concrete wastewater infrastructure and to discuss concepts that should be considered in the development of test methods to evaluate MIC in the laboratory.

\section{GENERATION OF SULFIDES}

The presence of dissolved sulfides in the waste stream is required for the formation of $\mathrm{H}_{2} \mathrm{~S}$, a component necessary to initiate MIC in sewer networks. Although sulfides may be present in wastewater as a result of industrial processes, the formation of $\mathrm{H}_{2} \mathrm{~S}_{(a \mathrm{ag})}$ is most commonly attributed to the activity of anaerobic sulfatereducing bacteria (SRB). Parker (1947) first named Sporovibrio desulfuricans as the organism responsible for the reduction of sulfates to $\mathrm{H}_{2} \mathrm{~S}_{(a q)}$. More recent molecular surveys of biofilm communities in sewers have revealed the presence of several SRB species (Santo Domingo et al., 2011) present in wastewater; however, Desulfovibrio desulfuricans is commonly named as the primary contributor to the sulfate reduction in municipal wastewater collection systems. Desulfovibrio desulfuricans is an obligate anaerobe that relies on the availability of organic substances for food supply (electron donor) and utilizes sulfate as an oxygen source (electron acceptor). The presence of both organic substances and sulfates is therefore necessary for the biological production of sulfides. Equation (1) describes the formation of hydrogen sulfide through the reduction of sulfates by SRB where $\mathrm{C}$ represents organic matter.

$$
\mathrm{SO}_{4(\mathrm{aq})}^{2-}+2 \mathrm{C}+\mathrm{H}_{2} \mathrm{O} \rightarrow 2 \mathrm{HCO}_{(\mathrm{aq})}^{3-}+\mathrm{H}_{2} \mathrm{~S}_{(\mathrm{aq})}
$$

The majority of sulfate reduction takes place in anaerobic slime layers, or biofilms, present on surfaces below the waterline. A biofilm is an established layer of microorganisms and organic materials known as extracellular polymeric substances (EPSs; Donlan, 2002). The thickness of the biofilm present in concrete sewer pipes is typically between 0.3 and $1.0 \mathrm{~mm}$, depending on the velocity of flow and frequency of abrasion by solids in the waste stream (U.S. Center for Environmental Research Information, 1985). In the case of a waste stream with an appreciable dissolved oxygen (DO) content, the biofilm will contain aerobic SOM at the liquid/ biofilm interface. As oxygen diffuses into the biofilm, it is consumed by the SOM, resulting in a gradient of DO that approaches zero near the structure wall. Beyond the highly aerobic zone is a SRB population that proliferates in the oxygen deficient conditions. Nearest to the concrete surface resides a layer of inert anaerobic bacteria whose activity is limited by the diffusion of organic food substances into the biofilm. Sulfates from the waste stream diffuse into the biofilm toward the anaerobic zone where they can be reduced to sulfide as described in Equation (1). Under conditions with sufficient DO, sulfides will be partially or completely oxidized by SOM as they diffuse back toward the waste stream. Any sulfide that escape the biofilm will undergo chemical or biological oxidation in the aqueous phase before release to the gas phase is possible. Under anoxic conditions, sulfides will diffuse out the biofilm unimpeded and partition into the waste stream where they may later partition to the gas phase. 
The DO content required for the buildup of sulfides in wastewater is subject to some debate. Early work showed that the conversion of sulfates to sulfides can only occur under conditions completely devoid of DO (U.S. EPA, 1974); however, other researchers have place the DO threshold for sulfide buildup in the waste stream at $0.1 \mathrm{mg} / \mathrm{L}$ (Hewayde, Nehdi, Allouche, \& Nakhla, 2006). Values as high as $0.5 \mathrm{mg} / \mathrm{L}$ (Ayoub, Azar, Fadel, \& Hamad, 2004) have been proposed, although the lack of corrosion observed in areas where sewage has an appreciable DO has led to questioning of that value (O'Connell, McNally, \& Richardson, 2010).

Factors influencing the DO concentration in wastewater include temperature, biochemical oxygen demand (BOD), and turbulence, among others. Increased temperature decreases oxygen solubility and promotes bacterial activity leading to the depletion of DO. High BOD also encourages bacterial growth and consumption of DO. Turbulence in the stream will encourage re-aeration and an increase in DO levels. DO content in the waste stream can be predicted using empirical relationships that account for both the consumption of dissolved oxygen by microorganisms and re-aeration from turbulence encountered by the wastewater. Table 1 summarizes wastewater characteristics that affect the generation and accumulation of sulfides in wastewater collection networks.

Table 1. Factors affecting sulfide content in wastewater collection networks.

\begin{tabular}{|c|c|}
\hline Factor & Effect \\
\hline DO & $\begin{array}{l}\text { Low DO encourages activity of SRB and the } \\
\text { conversion of sulfates to sulfides }\end{array}$ \\
\hline Sulfate Content & $\begin{array}{l}\text { Sulfates must be present for the biological } \\
\text { conversion to sulfide }\end{array}$ \\
\hline Temperature & $\begin{array}{l}\text { Increased temperatures encourage bacterial } \\
\text { activity and lower oxygen solubility }\end{array}$ \\
\hline BOD & $\begin{array}{l}\text { BOD represents nutrients available for } \\
\text { bacteria that deplete DO }\end{array}$ \\
\hline Turbulence & $\begin{array}{l}\text { Encourages re-aeration resulting in growth } \\
\text { of SOM and chemical oxidation resulting in } \\
\text { lowered potential for sulfide buildup }\end{array}$ \\
\hline
\end{tabular}

Little information is available regarding sulfide formation in structures where flow conditions are quasistatic, such as septic tanks or wastewater storage tunnels. The detachment of biofilm is heavily influenced by fluid shear and physical abrasion (Zhang, 2011). Unlike the conditions in actively flowing sewer pipes, the lack of significant fluid shear and physical abrasion under quiescent conditions is likely to result in a thicker biofilm on surfaces below the waterline. Whether this condition results in higher production rates of sulfides in the waste stream has not been investigated.

\section{PARTITIONING OF AQUEOUS $\mathrm{H}_{2} \mathrm{~S}$ INTO AIR}

The biological oxidation of $\mathrm{H}_{2} \mathrm{~S}_{(\mathrm{g})}$ to sulfuric acid on concrete surfaces is reliant on the availability of $\mathrm{H}_{2} \mathrm{~S}_{(\mathrm{g})}$ in the sewer headspace. Once present in the waste stream, the release of $\mathrm{H}_{2} \mathrm{~S}_{(\mathrm{aq})}$ into the gas phase will be heavily influenced by the $\mathrm{pH}$ of the wastewater, the equilibrium conditions between gas and liquid phases, temperature, and the turbulence of the flow. Speciation of $\mathrm{H}_{2} \mathrm{~S}$ in the aqueous phase is governed by the reversible ionization reaction shown below.

$$
\mathrm{H}_{2} \mathrm{~S}_{(\mathrm{aq})} \leftrightarrow \mathrm{HS}_{(\mathrm{aq})}^{-}+\mathrm{H}^{+}
$$

While $\mathrm{H}_{2} \mathrm{~S}_{(\text {aq) }}$ is able to partition to the gas phase, hydrosulfide, $\mathrm{HS}^{-}{ }_{(\mathrm{aq})}$ is not. Therefore, the dissociation behavior according to Equation 2 is particularly important to consider. The equilibrium speciation of $\mathrm{H}_{2} \mathrm{~S}_{(\mathrm{aq})}$ is dependent on solution $\mathrm{pH}$ as shown in Figure 2. Typical $\mathrm{pH}$ values of municipal wastewater range from 6.0 to 8.0 . From Figure 2, it is clear that $\mathrm{H}_{2} \mathrm{~S}(\mathrm{aq})$ will become the dominate species as $\mathrm{pH}$ falls below a value of 7 .

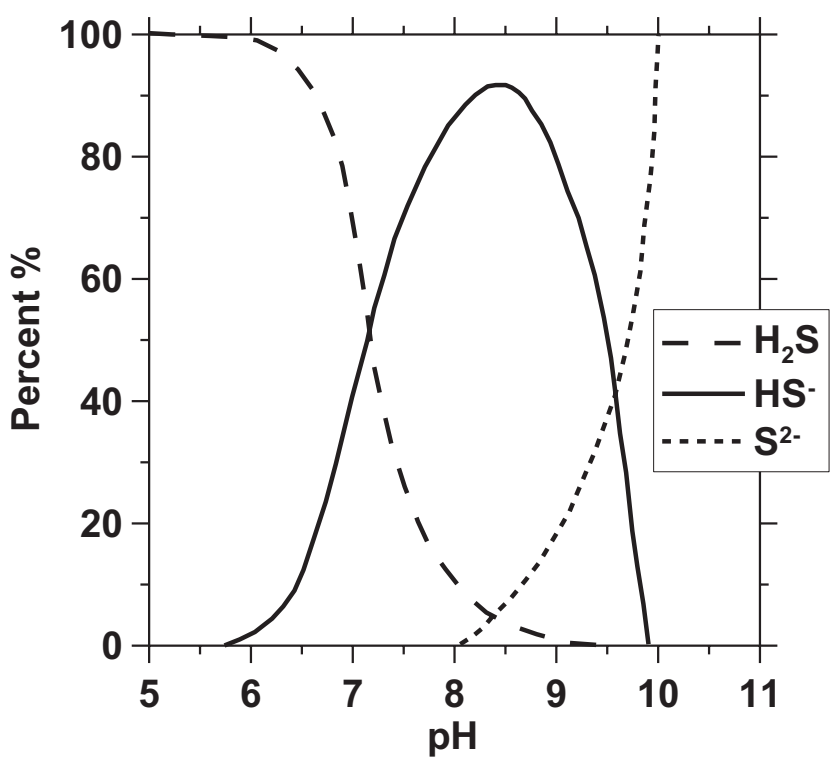

Figure 2. Equilibrium speciation of aqueous hydrogen sulfide as a function of $\mathrm{pH}$ (after U.S. center for environmental research information, 1985).

Under closed conditions, the propensity for $\mathrm{H}_{2} \mathrm{~S}_{(\text {aq) }}$ to transition from liquid to gas will be driven by the concentrations in each phase. The transition from liquid to gas is governed by Henry's Law:

$$
S_{\mathrm{g}}=k P_{\mathrm{g}} \text {, }
$$

where $S_{g}$ is the molar concentration of $\mathrm{H}_{2} \mathrm{~S}$ in the solution phase, $k$ is the applicable Henry's Law constant, and $P_{g}$ represents the partial pressure of $\mathrm{H}_{2} \mathrm{~S}$ 
in the air over solution. Figure 3 displays equilibrium concentrations of gaseous $\mathrm{H}_{2} \mathrm{~S}$ in a closed system as a function of temperature and $\mathrm{H}_{2} \mathrm{~S}$ concentration in solution. An increase in temperature results in decreased gas solubility and increased gaseous concentration.

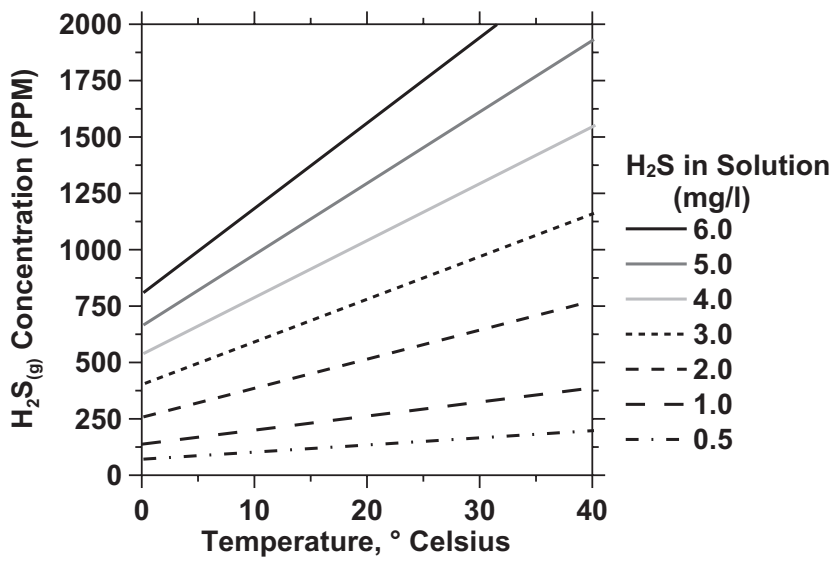

Figure 3. Concentration of $\mathrm{H}_{2} \mathrm{~S}$ in air in a closed system as a function of temperature and $\mathrm{H}_{2} \mathrm{~S}$ concentration in solution after U.S. center for environmental research information, 1985).

The buildup of $\mathrm{H}_{2} \mathrm{~S}_{(\mathrm{g})}$ in the sewer headspace will be dependent on the ventilation conditions within the network. Systems with adequate ventilation will encourage the release of $\mathrm{H}_{2} \mathrm{~S}$ into the gas phase but may limit the concentration of gas buildup. The $\mathrm{H}_{2} \mathrm{~S}_{(\mathrm{g})}$ concentrations in the headspace of systems with poor ventilation will tend toward the equilibrium values displayed in Figure 3. Both types of systems will be subject to the effects of temperature variations within the network. Increases in $\mathrm{H}_{2} \mathrm{~S}_{(\mathrm{g})}$ concentrations have been observed to correspond with daily and seasonal variations in temperature. $\mathrm{H}_{2} \mathrm{~S}_{(\mathrm{g})}$ concentrations within the headspace of a test section of concrete pipe in South Africa varied from as high as 110 PPM at the warmest part of the day to less than 40 PPM in the coolest part of the night (Alexander \& Fourie, 2011).

Turbulence in wastewater collection networks exacerbates the release of $\mathrm{H}_{2} \mathrm{~S}_{(\text {aq) }}$ into the sewer headspace by increasing the surface area of the water-air interface. Turbulence can result from high flow velocities, sudden drops, hydraulic jumps, or poor sewer construction. High levels of corrosion are often observed in turbulent areas such as manholes, lift stations, and junction boxes.

\section{OXIDATION OF $\mathrm{H}_{2} \mathrm{~S}_{(\mathrm{g})}$ TO SULFURIC ACID}

Once present in the sewer headspace, $\mathrm{H}_{2} \mathrm{~S}_{(\mathrm{g})}$ is free to partition into moisture films present on surfaces above the water line. Back in solution, $\mathrm{H}_{2} \mathrm{~S}_{(\mathrm{aq})}$ is subject to both biological (biotic) and chemical (abiotic) conversion to multiple oxidation states, ultimately leading to the production of sulfuric acid and the corrosion of the cement paste portion of the concrete matrix. Sulfur oxidation states are dependent on the local $\mathrm{pH}$ and the activity of sulfur oxidizing microorganisms (SOMs) present (Islander et al., 1991). Regardless of the path taken, the presence of $\mathrm{H}_{2} \mathrm{~S}_{(\mathrm{aq})}$ is the precursor to sulfuric acid production that defines MIC of concrete in wastewater networks.

The creation of sulfuric acid by abiotic oxidation is dependent on local $\mathrm{pH}$. At low $\mathrm{pH}, \mathrm{H}_{2} \mathrm{~S}_{(\mathrm{aq})}$ can be oxidized directly to elemental sulfur. Oxidation to sulfate $\left(\mathrm{SO}_{4}{ }^{2-}\right)$ takes place at higher $\mathrm{pH}$ levels with thiosulfate $\left(\mathrm{S}_{2} \mathrm{O}^{3-}\right)$ as an intermediate.

Abiotic oxidation alone does not create the highly acidic conditions that degrade concrete during MIC. The activity of SOM is necessary to oxidize $\mathrm{H}_{2} \mathrm{~S}_{(a q)}$ and intermediate products to sulfuric acid. Parker (1947) was the first to name Thiobacillus concretivorous, later identified as Thiobacillus thiooxidans as the organism capable of producing sulfuric acid resulting in $\mathrm{pH}$ levels as low as 1.0 on concrete surfaces. Since then five species of Thiobacillus have been identified as contributors to MIC in concrete wastewater networks: $T$. thioparus, $T$. novellus, $T$. neapolitanus, $T$. intermedius, and T. thiooxidans (Islander et al., 1991). The presence of some or all of these microorganisms on corroded sewer pipes has been confirmed by multiple researchers through the use of genetic analysis (Davis, Nica, Shields, \& Roberts, 1998; Okabe, Odagiri, Ito, \& Satoh, 2007; Santo Domingo et al., 2011; Vincke, Boon, \& Verstraete, 2001).

The presence and abundance of each Thiobacillus species are heavily dependent on the availability of nutrients and the $\mathrm{pH}$ on the concrete surface. The preferred substrates and $\mathrm{pH}$ ranges for growth of SOM involved with MIC are summarized in Table 2.

Fresh concrete is highly alkaline, often exhibiting $\mathrm{pH}$ between 12.5 and 13.5 (Mehta \& Monteiro, 1993). Abiotic lowering of the concrete surface $\mathrm{pH}$ is therefore necessary before colonization by Thiobacillus can occur. Carbonation, the process by which atmospheric carbon dioxide reacts with calcium hydroxide and water within the cement microstructure, is typically credited with the

Table 2. Preferred substrates and ph ranges for som involved with mic in concrete sewer networks (Islander et al., 1991; Madigan, 2006).

\begin{tabular}{llc}
\hline Species & Preferred substrate & $\begin{array}{c}\text { Preferred pH } \\
\text { growth range }\end{array}$ \\
\hline T. thioparus & $\mathrm{H}_{2} \mathrm{~S}, \mathrm{~S}^{0}, \mathrm{~S}_{2} \mathrm{CO}_{3}^{2-}$ & $5-9$ \\
T. novellus & $\mathrm{S}_{2} \mathrm{CO}_{3}^{2-}$ & $2.5-8$ \\
T. intermedius & $\mathrm{S}_{2} \mathrm{CO}_{3}^{2-}$ & $2.5-8$ \\
T. neapolitanus & $\mathrm{S}^{0}, \mathrm{~S}_{2} \mathrm{CO}_{3}^{2-}$ & $3-7$ \\
T. thiooxidans & $\mathrm{H}_{2} \mathrm{~S}, \mathrm{~S}^{0}$ & $0.5-3$ \\
\hline
\end{tabular}


initial reduction in surface $\mathrm{pH}$ of the concrete. Leaching of calcium hydroxide through contact with wastewater along with the growth of other microorganisms may also lead to a reduction in $\mathrm{pH}$ near the concrete surface. Once the concrete surface reaches a pH value of 9-10, colonization by $T$. thioparus begins. After SOM are established, abiotic lowering of the concrete $\mathrm{pH}$ is no longer relevant as biological production of sulfuric acid governs the surface $\mathrm{pH}$. Colonization by $T$. Thioparus is followed by a successive establishment of more acidophilic species of Thiobacillus. Islander et al. (1991) proposed the reduction in concrete surface $\mathrm{pH}$ and succession of microorganisms illustrated in Figure 4.

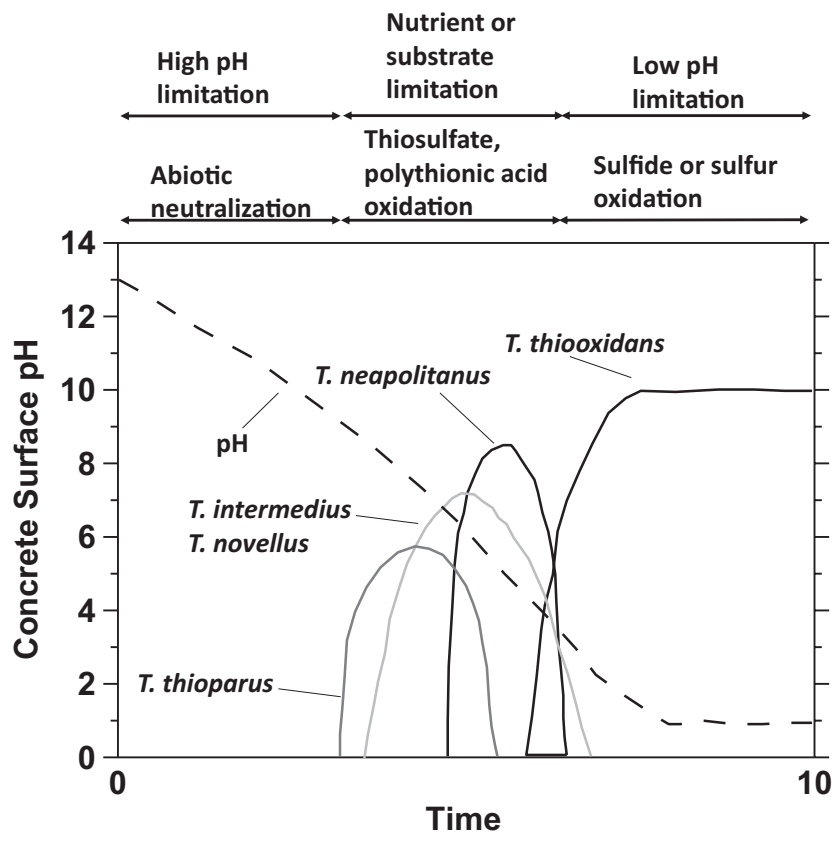

Figure 4. Theorized succession of aerobic sulfur-oxidizing bacteria on corroding concrete surfaces exposed to wastewater (after Islander et al., 1991).

As many as four species may be present on sewer walls at $\mathrm{pH}$ values of 3.0-8.0. T. thioparus makes use of sulfides, elemental sulfur, and thiosulfate in the production of sulfuric acid. T. intermedius and $T$. novellus are the next species to colonize the surface, relying mainly on thiosulfate as a substrate. $\mathrm{As} \mathrm{pH}$ is reduced to below $7, T$. neapolitanus becomes prevalent until surface $\mathrm{pH}$ is reduced to around 3 . Being highly acidophilic, $T$. thiooxidans thrives at $\mathrm{pH}$ values below 3 where it oxidizes both sulfides and elemental sulfur to sulfuric acid. T. Thiooxidans continues to lower the surface $\mathrm{pH}$ until acid production becomes selfinhibitory at $\mathrm{pH}$ values from 0.5 to 1.0 .

This succession of microorganisms has become somewhat of a tool in evaluating the state of corrosion in wastewater networks. Most concrete is able to withstand mildly acid conditions with a $\mathrm{pH}$ above 6.0. Therefore, the presence of neutrophilic sulfur-oxidizing microorganisms (NSOM) such as T. thioparus does not imply an immediate risk of significant corrosion. The presence of these organisms does, however, indicate the potential for a further ecological succession of acidophilic sulfur-oxidizing microorganisms (ASOM) to species such as $T$. thiooxidans that are associated with severe corrosion. Davis et al. (1998) investigated corroded sewer pipes and observed that the presence of NSOM was associated with mild corrosion where high numbers of ASOM were associated with severe corrosion in the crown of sewer pipes. Vincke et al. (2001) also affirmed this observation by consistently finding ASOM in highly corroded sections of sewer pipe.

It is worth noting that Thiobacillus bacteria are not the only microorganisms present on corroding sewer walls. Aerobic heterotrophs, fungi, and others are commonly found in high numbers alongside Thiobacillus. The role that these microorganisms play in the corrosion process, if any, has not been defined.

\section{MECHANISMS OF ACID DEGRADATION}

The end product of the oxidation of $\mathrm{H}_{2} \mathrm{~S}$ by SOM is sulfuric acid. As such it is important to understand the mechanics of acid attack in cementitious materials. The chemical composition of hydrated Portland cement makes the majority of concrete susceptible to degradation when exposed to acidic conditions (Duchesne \& Bertron, 2013; Mehta \& Monteiro, 1993). The volume occupied by hydrated cement paste is generally composed of the following proportions of four solid products: $50-60 \%$ calcium silica hydrate (CSH), 20-25\% calcium hydroxide $(\mathrm{CH}), 15-20 \%$ calcium sulfoaluminates, and varying amounts of unhydrated cement grains (Mehta \& Monteiro, 1993). Exposure to acid results in the decalcification of these hydrated products, beginning with $\mathrm{CH}$, and the eventual breakdown of the microstructure resulting in increased porosity and a decrease in mechanical properties (Duchesne \& Bertron, 2013; Pavlík, 1994a). After decalcification, calcium ions either diffuse out of the microstructure or combine with the salt of the acid to form insoluble calcium salts of little structural value. The presence of these products results in the formation of a porous layer on the concrete surface. Degradation continues as hydrated products become more unstable with decreasing alkalinity in the system.

The degradation mechanisms and severity of acid attack on concrete are dependent on the type of attack as well as the strength and type of acid. The ability of concrete to resist acid attack is related to acid neutralization capacity, composition of hydrated products, and porosity.

To properly address the acid attack found in MIC of concrete structures, a distinction must be made between what could be considered "passive" and 
"active" acid attack. Passive attack could be defined as exposure to a finite amount of nonflowing acid. Examples of passive acid attack of concrete are periodic exposure to aggressive acid solutions in an industrial setting or occasional exposure to acid rain. Active acid attack could be defined as sustained exposure to acid that cannot be effectively neutralized over a long period by the alkalinity found in concrete. MIC of concrete sewer infrastructure is an active degradation process where continuous biological production of acid results in sustained attack of the concrete surface. Another example of active attack includes underground concrete structures exposed to flowing groundwater of acidic nature or storage of large volumes of acidic material. Evaluating concrete performance under passive conditions is useful in understanding the mechanisms of acid attack on concrete; however, it is important to understand that some mechanics will change under active conditions.

Under passive attack, the corrosion product layer controls the rate of corrosion by limiting the diffusion of acid toward the thin zone where reaction with unaffected cement paste takes place (Pavlík, 1994b). Figure 5 presents a simplified illustration of acid corrosion of cement paste under passive attack. The characteristics of the corrosion product layer are dependent on the solubility of the compounds and the amount of physical abrasion available for removal of the layer.

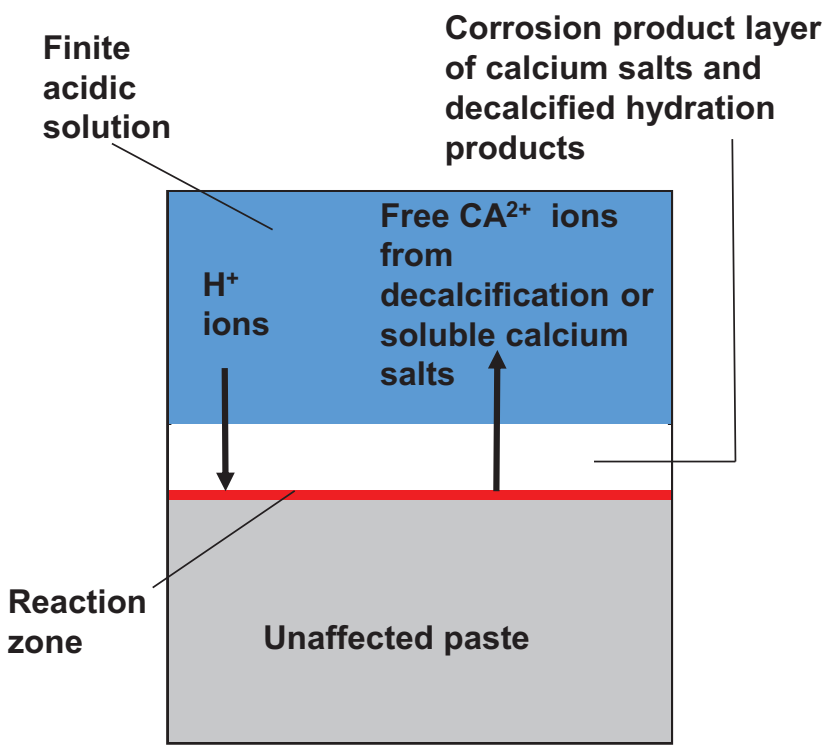

Figure 5. Graphical representation of passive acid attack on cement paste.

Under active acid attack found in MIC, the role of this corrosion layer is changed completely. While acid produced on the surface of this layer will have to diffuse through the corroded layer to reach unaffected concrete, there is strong evidence that this layer supports the growth of SOM throughout its thickness. Davis et al. (1998) found high numbers of ASOM in both the outer and inner regions of the corrosion product layer on the crown of a corroded sewer pipe. Furthermore, NSOM found in the outer region of the corrosion product layer was not present in the inner region, suggesting that conditions near the interface of the corrosion products and unaffected concrete were the most acidic. These results suggest that the corrosion product layer plays less of a role in inhibiting active acid attack by SOM compared with passive attack. The layer actually encourages the growth of SOM and the deposition of acid near the reaction zone. Figure 6 represents the mechanisms of active acid attack of cement paste by SOM.

\section{Outer corrosion product layer - contains NSOM, ASOM. Continual acid production.}

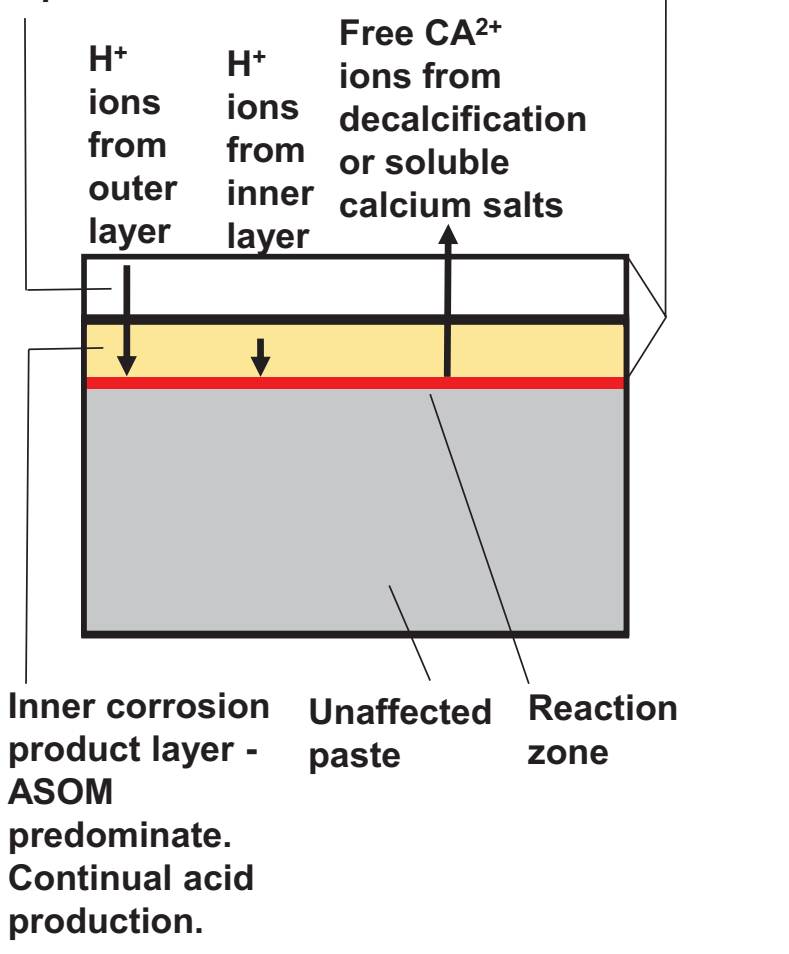

Figure 6. Graphical representation of cement paste under active acid attack by SOM.

The strength of the acid has several effects on the mechanism of acid corrosion in concrete materials. Degradation in mildly acidic solutions characteristic of municipal wastewater is attributed to leaching of calcium ions over a long period. The slow dissolution and loss of calcium hydroxide by diffusion can eventually lead to a reduction in structural integrity and mechanical properties (Carde, François, \& Torrenti, 1996); however, the timeline for this type 
of degradation is only a concern for structures with design lives in the order of thousands of years (Hidalgo, Andrade, \& Alonso, 2001) and is negligible in wastewater collection networks when compared with the short-term threat presented by MIC. Under highly acidic conditions, the dissolution of calcium hydroxide is accompanied by the decalcification of less soluble hydration products such as $\mathrm{CSH}$, sulfoaluminates, and ferroaluminates. Calcium ions will combine with the salts of the acid to form variably soluble calcium salts. If highly soluble in water, these salts will diffuse away from the surface. The decalcified remains of the less soluble hydration products are retained on the concrete surface in the form of amorphous hydrated oxides including gels of $\mathrm{SiO}_{2(\mathrm{aq})}, \mathrm{Al}_{2} \mathrm{O}_{3(\mathrm{aq})}, \mathrm{Fe}_{2} \mathrm{O}_{3(\mathrm{aq})}$, and small amounts of $\mathrm{CaO}$ or MgO (Pavlík \& Unčík, 1997). Increasing acidity results in the loss of $\mathrm{Al}_{2} \mathrm{O}_{3(\mathrm{aq})}$ and $\mathrm{Fe}_{2} \mathrm{O}_{3(\mathrm{aq})}$ to solution due to increased solubility at $\mathrm{pH}$ values below approximately 4 and 2 , respectively. Increasing acidity can also affect the solubility of any calcium salts present in the corroded products layer. The strength of the relevant acid is therefore important in the initial degradation mechanism as well as the stability of the resulting corrosion products.

Whether an acid is strong or weak will affect the development of the corrosion layer during acid attack. Strong acids tend to develop more soluble calcium salts compared with insoluble salts formed by weak acids (Pavlík \& Unčík, 1997) and complete dissociation of strong acids results in more severe degradation when compared with the same concentration of weak acids (Duchesne \& Bertron, 2013). In the case of sulfuric acid present in MIC, the reaction between sulfuric acid and hydrated cement products is particularly aggressive (Monteny etal., 2000; O'Connell etal., 2010). Dissolution of $\mathrm{CH}$ and decalcification of $\mathrm{CSH}$ is accomplished by the hydrogen ion. $\mathrm{CH}$ then combines with sulfate to form the expansive product gypsum. Gypsum may then react with aluminate phases to form ettringite. The formation of gypsum and ettringite is theorized to produce stress cracking within the matrix due to the increased volume occupied by these products. A layer of gypsum is formed on the surface of the concrete as corrosion occurs, and while gypsum solubility increases with increasing concentration of sulfuric acid (Azimi, Papangelakis, \& Dutrizac, 2007), it remains stable at $\mathrm{pH}$ values commonly found on corroded sewer pipes. The following reactions summarize the decalcification of $\mathrm{CSH}$ gel and dissolution of calcium hydroxide by sulfuric acid and the subsequent formation of gypsum and ettringite (Monteny et al., 2000):

$$
\begin{gathered}
\mathrm{CaO} \cdot \mathrm{SiO}_{2} \cdot 2 \mathrm{H}_{2} \mathrm{O}+\mathrm{H}_{2} \mathrm{SO}_{4} \rightarrow \mathrm{CaSO}_{4}+\mathrm{Si}(\mathrm{OH})_{4}+\mathrm{H}_{2} \mathrm{O} \\
\mathrm{Ca}(\mathrm{OH})_{2}+\mathrm{H}_{2} \mathrm{SO}_{4} \rightarrow \mathrm{CaSO}_{4}+2 \mathrm{H}_{2} \mathrm{O}
\end{gathered}
$$

$$
\begin{gathered}
3 \mathrm{CaSO}_{4} \cdot 2 \mathrm{H}_{2} \mathrm{O}+3 \mathrm{CaO} \cdot \mathrm{Al}_{2} \mathrm{O}_{3}+26 \mathrm{H}_{2} \mathrm{O} \rightarrow \\
(\mathrm{CaO})_{3} \cdot\left(\mathrm{Al}_{2} \mathrm{O}_{3}\right) \cdot\left(\mathrm{CaSO}_{4}\right)_{3} \cdot 32 \mathrm{H}_{2} \mathrm{O}
\end{gathered}
$$

The presence of both gypsum and ettringite have been confirmed with X-ray diffraction on corroded samples from laboratory experiments (Mori et al., 1992) and field studies (Davis et al., 1998).

Acid neutralization capacity (ANC) or alkalinity is the ability of a material to resist change in $\mathrm{pH}$ in the presence of acid. The alkalinity of hydrated cement is therefore important in maintaining the stability of hydrated products sensitive to a reduction in $\mathrm{pH}$. While the ANC of cementitious materials is important when considering exposure to mildly acidic solutions (Chen, Zhang, Ke, Hills, \& Kang, 2009), or passive attack, its role upon exposure to active acid attack is less apparent. Neglecting the effects of the corrosion product layer, Beddoe and Dorner (2005) proposed a second-order relationship to describe the neutralization of alkalinity in concrete upon exposure to acid. Equation (7) describes the relationship:

$$
\frac{\partial C_{\mathrm{Ca}}}{\partial r}=k_{\mathrm{Ca}} C_{\mathrm{H}} s_{\mathrm{Sa}}
$$

where $C_{\mathrm{Ca}}$ is the amount of available soluble calcium, $C_{H}$ is the concentration of protons in the pore solution, $k_{\mathrm{Ca}}$ is a rate constant, and $s_{\mathrm{Sa}}$ is the amount of potentially soluble calcium inconcrete with respect to pore solution volume. Under passive attack, the magnitude of damage is governed by a balance of calcium available for neutralization and acid available for attack. Under active corrosion conditions, however, the available acid is not decreased with time, resulting in a continual depletion of calcium and destabilization of the cement paste.

Porosity is generally regarded as the most important characteristic for predicting the durability and mechanical properties in hydrated cementitious systems. In general, reducing the porosity of concrete is associated with an increase in strength and a reduction in transport properties. Durability of concrete is heavily influenced by the transport of aggressive substances into the microstructure via diffusion through the pore network. Reducing porosity by lowering the $w / \mathrm{cm}$ or replacing a portion of Portland cement with pozzolanic supplementary cementitious materials (SCMs) are traditional strategies to prevent the ingress of deleterious substances such as chlorides and sulfates.

The role of porosity in the resistance of concrete to acid attack is not straightforward. The depth that hydrogen ions can diffuse into the concrete microstructure is severely limited by the reaction with the alkaline 
constituents of the pore solution (Beddoe \& Dorner, 2005); therefore, the porosity of the hydrated cement appears to have only a secondary effect on the rate of corrosion. It is thought that the physical characteristic of the corrosion product layer is dependent on the properties of the undamaged cementitious matrix. In that sense, concrete with low w/cm will tend to develop a denser, less permeable layer of corrosion products. As a result, the diffusion of acid through the corroded layer and the rate of reaction with unaffected cement and therefore degradation will be reduced. This is, however, assuming a passive acid attack mechanism. The growth of ASOM in the corrosion layer during active attack such as MIC may negate this effect.

A search of the literature regarding the subject offers conflicting results. Pavlík (1996) found that increasing the $\mathrm{w} / \mathrm{c}$ of cement paste from 0.30 to 0.70 resulted in a $50 \%$ increase in corrosion depth when exposed to nitric acid. Fattuhi and Hughes (1988) reported that an increase in w/c from 0.26 to 0.40 resulted in a $24 \%$ reduction in mass loss of cement paste cubes when exposed to sulfuric acid. Hewayde, Nehdi, Allouche, and Nakhla (2007) found a 13\% reduction in mass loss of concrete cylinders exposed to sulfuric acid when w/c was increased from 0.25 to 0.50 . In many studies, it is difficult to isolate the role of porosity in acid resistance. For example, increasing w/c ratio inherently reduces cement content per unit volume of cement paste. As a result, the effects of porosity and alkalinity are interconnected. Mehta (1985) stated that acid corrosion of low w/c concrete is more of a surface phenomenon, whereas the role of transport through the pore network becomes more prevalent in high w/c concrete. It is clear that more work is necessary to clearly define the role of porosity in the resistance of concrete to acid attack.

\section{PROPOSING MIC A THREE-STAGE PROCESS}

A theoretical model has been proposed (House, 2013) that outlines a three-stage MIC degradation process. This is shown in Figure 7.

Stage 1 of the corrosion process is abiotic lowering of the concrete surface $\mathrm{pH}$. For concrete pipes and tanks, this can occur with the abiotic processes as proposed by Islander et al. (1991) including carbonation or exposure to wastewater. In general, the concrete mixture design has minimal influence on the rate or extent of surface carbonation and the associated lowering of surface $\mathrm{pH}$. It should be noted that this differs from carbonation problems associated with steel corrosion in concrete where the depth of the carbonation penetration is the key issue. Carbonation in this context only needs to occur at the surface-a process that occurs quickly and is difficult to prevent in practice.

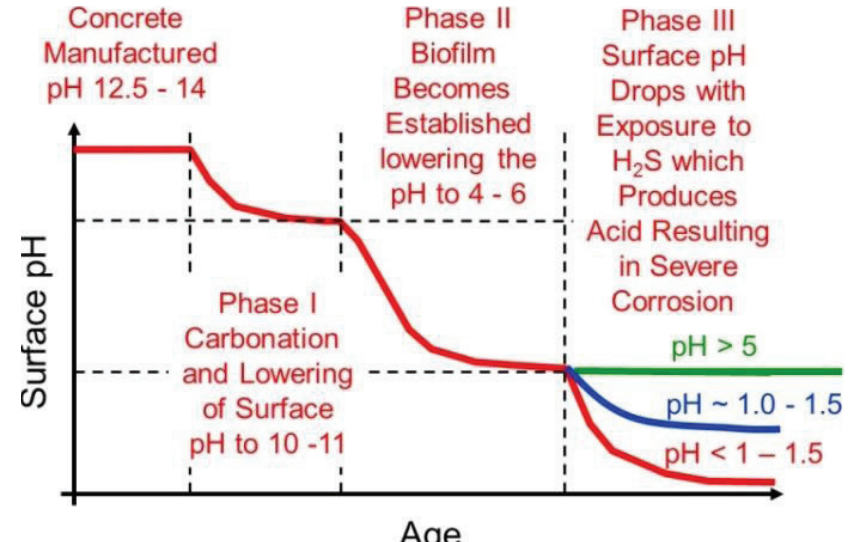

Age

Figure 7. Three-stage process of MIC corrosion (House, 2013).

Stage 2 represents the lowering of concrete surface $\mathrm{pH}$ due to attachment, initiation of growth, and the succession of Thiobacillus species with or without the presence of $\mathrm{H}_{2} \mathrm{~S}_{(\mathrm{g})}$. With limited nutrients in the absence of $\mathrm{H}_{2} \mathrm{~S}_{(\mathrm{g})}$, the rate of surface $\mathrm{pH}$ reduction during this stage is relatively independent of concrete mixture design under the growth conditions provided (House, 2013). This rate may accelerate in the presence of high levels of $\mathrm{H}_{2} \mathrm{~S}_{(\mathrm{g})}$. It should also be noted that if the attachment and growth processes could be interrupted (as proposed by several antimicrobial materials), bacterial activity and sulfuric acid production may be inhibited, and the $\mathrm{pH}$ at the surface would not be expected to decrease. These claims need to be verified.

After Stage 2, the $\mathrm{pH}$ at the surface of the concrete has reduced to a stage where it may be susceptible to acid attack. Stage 3 represents severe corrosion in the presence of hydrogen sulfide gas. It is believed that the concentration of hydrogen sulfide gas plays an important role in the rate and magnitude of sulfuric acid production during this stage and the associated rate of concrete corrosion. It is possible that sulfuric acid immersion studies could be used to mimic this stage of the corrosion process based on the surface $\mathrm{pH}$ values recorded under field conditions. Future work is needed to assess the corrosion rate dependence on the concentration of hydrogen sulfide gas.

\section{SUGGESTIONS FOR TEST METHODS}

The development of a single comprehensive test method for the evaluation of concrete resistance to $\mathrm{MIC}$ is inherently complex due to the multistage nature of the degradation process and the combination of biological and physicochemical processes that take place. To better understand the MIC process, it may be more useful to investigate each stage separately based on a corrosion model such as the one presented above. It cannot be emphasized enough that MIC is not solely a material issue. The corrosion behavior will 
vary based on the unique environmental conditions, waste stream behavior, structural characteristics, and material properties present in each case.

Investigation of Stage 1 may appear at first to be similar to efforts to reduce carbonation associated with the corrosion of reinforcing steel. However, this differs in the fact that corrosion of reinforcing steel depends on the penetration of carbonation front while the carbonation associated with MIC is really related to the outermost surface. Preventing or delaying surface carbonation may slow the attachment of Thiobacillus and delay the onset of MIC; however, as stated previously, this process occurs nearly immediately after production and is difficult to control in the field since it may also occur simply due to the leaching of calcium hydroxide. Therefore, it appears to the authors that efforts may be better spent focusing on testing for stages 2 and 3 .

Stage 2 involves with the attachment and growth of Thiobacillus bacteria on the concrete surface. Disrupting bacterial establishment could slow or prevent the establishment and succession of Thiobacillus and therefore the production of sulfuric acid and subsequent MIC. Antimicrobial concrete admixtures may offer the potential to interfere with bacterial growth; however, their effectiveness has not been thoroughly investigated in the lab or rigorously tested in the field. Further work is necessary to understand the biological processes during the bacterial succession and identify opportunities to disrupt these processes. There appears to be a potential benefit in the development of a test with investigating how well the bacteria attach and grow.

Stage 3 details the final stage of the MIC process and is defined by production of sulfuric acid and acid attack of concrete. The current literature suffers from a critical lack of data related to environmental conditions and corrosion rates. Thorough field investigations are necessary to correlate variables such as temperature, humidity, wastewater characteristics, ventilation, and hydrogen sulfide gas levels with surface $\mathrm{pH}$ values and severity of corrosion. Data from structures other than circular sewer pipes are particularly lacking (e.g., pumping stations, risers, and tanks). A relationship between bacterial production of sulfuric acid and hydrogen sulfide gas concentrations would be particularly useful; however, this type of investigation is not straightforward considering the many variables that contribute to bacterial activity.

\section{REFERENCES}

Alexander, M. G., \& Fourie, C. (2011). Performance of sewer pipe concrete mixtures with Portland and calcium aluminate cements subject to mineral and biogenic acid attack. Materials and Structures, 44, 313-330.
ASCE. (2013). 2013 Report card for America's infrastructure. Fairfax, VA: Author.

Ayoub, G., Azar, N., Fadel, M. E., \& Hamad, B. (2004). Assessment of hydrogen sulphide corrosion of cementitious sewer pipes: A case study. Urban Water Journal, 1, 39-53.

Azimi, G., Papangelakis, V., \& Dutrizac, J. (2007). Modelling of calcium sulphate solubility in concentrated multi-component sulphate solutions. Fluid Phase Equilibria, 260, 300-315.

Beddoe, R. E., \& Dorner, H. W. (2005). Modelling acid attack on concrete: Part I. The essential mechanisms. Cement and Concrete Research, 35, 2333-2339.

Carde, C., François, R., \& Torrenti, J.-M. (1996). Leaching of both calcium hydroxide and $\mathrm{C}-\mathrm{S}-\mathrm{H}$ from cement paste: Modeling the mechanical behavior. Cement and Concrete Research, 26, 1257-1268.

Chen, Q., Zhang, L., Ke, Y., Hills, C., \& Kang, Y. (2009). Influence of carbonation on the acid neutralization capacity of cements and cementsolidified/stabilized electroplating sludge. Chemosphere, 74, 758-764.

Davis, J. L., Nica, D., Shields, K., \& Roberts, D. J. (1998). Analysis of concrete from corroded sewer pipe. International Biodeterioration \& Biodegradation, 42, 75-84.

Diercks, M., Sand, W., \& Bock, E. (1991). Microbial corrosion of concrete. Experientia, 47, 514-516.

Donlan, R. M. (2002). Biofilms: Microbial life on surfaces. Emerging Infectious Diseases, 8, 881.

Duchesne, J., \& Bertron, A. (2013). Leaching of cementitious materials by pure water and strong acids ( $\mathrm{HCl}$ and $\mathrm{HNO} 3)$. In M. Alexander \& N. De Belie (Eds.), Performance of cement-based materials in aggressive aqueous environments Netherlands: Springer, 91-112.

Fattuhi, N., \& Hughes, B. (1988). The performance of cement paste and concrete subjected to sulphuric acid attack. Cement and Concrete Research, 18, 545-553.

Gutierrez-Padilla, M. G. D. (2007). Activity of sulfur oxidizing microorganisms and impacts on concrete pipe corrosion (3256409 Ph.D.). University of Colorado at Boulder, Boulder.

Hewayde, E., Nehdi, M., Allouche, E., \& Nakha, G. (2007). Effect of mixture design parameters and wetting-drying cycles on resistance of concrete to sulfuric acid attack. Journal of Materials in Civil Engineering, 19, 155-163.

Hewayde, E., Nehdi, M., Allouche, E., \& Nakhla, G. (2006). Effect of geopolymer cement on microstructure, compressive strength and sulphuric acid resistance of concrete. Magazine of Concrete Research, 58, 321-331. 
Hidalgo, A., Andrade, C., \& Alonso, C. (2001). Role of alkaline reserve in the acidic resistance of cement pastes. In J. Skalny, J. Gebauer, \& I. Odler (Eds.), Materials science of concrete, Special Volume (280p). John Wiley and Sons.

House, M. W. (2013). Using biological and physico-chemical test methods to assess the role of concrete mixture design in resistance to microbially induced corrosion (1549366 M.S.C.E.). Purdue University, West Lafayette.

Islander, R. L., Devinny, J. S., Mansfeld, F., Postyn, A., \& Shih, H. (1991). Microbial ecology of crown corrosion in sewers. Journal of Environmental Engineering, 117(6), 751-770.

Madigan, M. T. (2006). Brock biology of microorganisms. Upper Saddle River, NJ: Pearson Prentice Hall.

Mehta, P. (1985). Studies on chemical resistance of low water/cement ratio concretes. Cement and Concrete Research, 15, 969-978.

Mehta, P. K., \& Monteiro, P. J. (1993). Concrete: Structure, properties, and materials. Englewood Cliffs, NJ: Prentice Hall.

Monteny, J., Vincke, E., Beeldens, A., De Belie, N., Taerwe, L., Van Gemert, D., \& Verstraete, W. (2000). Chemical, microbiological, and in situ test methods for biogenic sulfuric acid corrosion of concrete. Cement and Concrete Research, 30, 623-634.

Mori, T., Nonaka, T., Tazaki, K., Koga, M., Hikosaka, Y., \& Noda, S. (1992). Interactions of nutrients, moisture and $\mathrm{pH}$ on microbial corrosion of concrete sewer pipes. Water Research, 26, 29-37.

O'Connell, M., McNally, C., \& Richardson, M. G. (2010). Biochemical attack on concrete in wastewater applications: A state of the art review. Cement and Concrete Composites, 32.

Okabe, S., Odagiri, M., Ito, T., \& Satoh, H. (2007). Succession of sulfur-oxidizing bacteria in the microbial community on corroding concrete in sewer systems. Applied and Environmental Microbiology, 73, 971-980.

Parker, C. (1947). Species of sulphur bacteria associated with the corrosion of concrete. Nature, 159, 439-440.

Parker, C. (1951). Mechanics of corrosion of concrete sewers by hydrogen sulfide. Sewage and Industrial Wastes, 23(12), 1477-1485.

Pavlík, V. (1994a). Corrosion of hardened cement paste by acetic and nitric acids part I: Calculation of corrosion depth. Cement and Concrete

Research, 24, 551-562.

Pavlík, V. (1994b). Corrosion of hardened cement paste by acetic and nitric acids part II: Formation and chemical composition of the corrosion products layer. Cement and Concrete Research, 24, 1495-1508.

Pavlík, V. (1996). Corrosion of hardened cement paste by acetic and nitric acids part III: Influence of water/cement ratio. Cement and Concrete Research, 26, 475-490.

Pavlík, V., \& Unčík, S. (1997). The rate of corrosion of hardened cement pastes and mortars with additive of silica fume in acids. Cement and Concrete Research, 27, 1731-1745.

Santo Domingo, J. W., Revetta, R. P., Iker, B., Gomez-Alvarez, V., Garcia, J., Sullivan, J., \& Weast, J. (2011). Molecular survey of concrete sewer biofilm microbial communities. Biofouling, 27, 993-1001.

Saricimen, H., Shameem, M., Barry, M., Ibrahim, M., \& Abbasi, T. (2003). Durability of proprietary cementitious materials for use in wastewater transport systems. Cement and Concrete Composites, 25, 421-427.

Thistlethwayte, D. K. B. (1972). The control of sulphides in sewerage systems. Ann Arbor, MI: Ann Arbor Science.

U.S. Center for Environmental Research Information. (1985). Odor and corrosion control in sanitary sewerage systems and treatment plants: Design manual. Center for Environmental Research Information, U.S. Environmental Protection Agency, Office of Research and Development.

U.S. EPA. (1974). Process design manual for sulfide control in sanitary sewerage systems, Washington, DC: Author.

U.S. EPA. (1991). Hydrogen sulfide corrosion in wastewater collection and treatment systems: Report to congress, Technical Report. Author.

Vincke, E., Boon, N., \& Verstraete, W. (2001). Analysis of the microbial communities on corroded concrete sewer pipes - a case study. Applied Microbiology and Biotechnology, 57, 776-785.

Zhang, W. (2011). Characterization of passive and active biofilm detachment (3480944 Ph.D.). Purdue University, West Lafayette. 